\title{
Learning from Experience: The Project Team is the Key
}

\author{
Mariya Terzieva \\ BTO Research, Italy \\ Vincenzo Morabito \\ Bocconi University, Italy
}

\begin{abstract}
Background: Learning from experience and knowledge management described in existing literature evidence that there are different practices that enable these processes, and that a distinction between implicit and explicit knowledge is essential for our analysis. Objectives: The paper investigates through which project management practices organizations manage the two types of knowledge and at what level knowledge sharing and reuse is more commonly adopted. Method/Approach: The research starts with existing research overview and analysis of preliminary results from initial interviews, and then it continues with a survey on selected knowledge management practices in order to identify which of them are mostly used by organizations. Results/Findings: Results show the essential role of the project team; this finding is then further elaborated using knowledge from research presented in existing literature. Conclusion: Project management enhances efficient knowledge management as on one hand, it includes the adoption of standardised and repetitive practises what enables specialization and knowledge consolidation. On the other hand, project management refers to unique initiatives that provide new knowledge and opportunities for learning. The project team in particular results to be a key factor for activating knowledge reuse.
\end{abstract}

Keywords: learning from experience; team; knowledge management; knowledge reuse; retrospectives; project management

JEL classification: L2, L29

Paper type: Research article

Received: June 01, 2015

Accepted: Dec 11, 2015

Citation: Terzieva, M., Morabito, V. (2016), "Learning from Experience: the Key is the Project Team", Business Systems Research, Vol. 7, No. 1, pp. 1-15.

DOI: 10.1515/bsri-2016-0001

\section{Introduction}

Individuals and organizations with no doubt learn from experience and in time gain more and more knowledge about themselves, about the way they work and about their customers (Walsh et al., 1991, Senge, 1994). But what do we actually do in order to learn from projects that we work on? Do organizations believe in knowledge 
management initiatives? Or is it true that in today's dynamic marketplace, and under continuous competitive pressure, organizations often tend to concentrate on moving from one project to another rather than focusing on their learning processes that require time and money?

Driven by these questions, the first part of this work aims to explain and examine organizational learning, and in particular, how project management relates to it. The second part of this paper will then investigate how, in different case studies; companies manage knowledge and what efforts are made for learning from project experience. We will conduct interviews and surveys in order to identify and analyse practices used by companies and explain their choices by exploring existing literature. We will observe that knowledge sharing and reuse result more frequently applied at team level.

\section{Background}

\section{Knowledge Management \& Organizational Learning}

Different authors have given different definitions to knowledge management (KM) (Collison et al., 2004, Nonaka et al., 1995, Pfeffer et al., 1999), and yet none of these definitions are completely accurate, nor are they completely imprecise. The correct definition of KM changes from organization to organization and KM programs are defined by organizational objectives and are intended to achieve specific outcomes. As suggested by authors, these can include improved performances, competitive advantage innovations; lessons learnt transfer (for example between projects) and the general development of collaborative practices (Buckley et al., 2013).

If we analyse the word "knowledge" we will find its origins in Latin where "know" derives from "noscere" and "ledge" may have originally meant "process" or "action", and then knowledge can be seen as the "capacity for effective action" (Senge et al., 1999).

Knowledge management seeks to improve performance by extending and maintaining the present and future value of knowledge assets (Newman et al., 1999). Creation, updating, sharing and use of knowledge have been recognized as an essential component of a proactively managed organization. The main notions refer to converting data, organizational insight, experience and expertise into reusable and useful knowledge that is distributed and shared with the people who need it. We would expect then, that if an organization manages knowledge successfully it will be able to use information and consult past experience. This process is useful and in some cases even crucial, to perform a job better than it has been done in the past.

A very interesting concept that helps understanding the importance of knowledge management is organizational memory (Walsh et al., 1991). The idea of organizational memory suggests that obtaining, storing, reuse and transfer of knowledge is very similar and functions in a very similar way to human brain. This concept is based on the idea that organizations are continuously learning due to the dynamic and competitive marketplace, and if they do not want to waste gathered knowledge they have to face the problem of elaborating new information and archiving the knowledge that they possess.

When talking about organizational learning, an important issue to outline is that the phenomenon goes way beyond individual learning (Fiol et al., 1985). Organizational learning is not a simple arithmetical sum of single individuals learning, but it generates value and memories over time even when members change and new ones join the company. Organizational memory is, in fact, located in individuals, 
technologies, organizational structures, and organizational culture and even in all routine activities. The processes concerning acquirement and assimilation of knowledge depend on the efforts and the dynamics made by the organization to capture new knowledge, by learning and sharing activities (Walsh et al., 1991).

In order to structure our research we will start with making a distinction between tacit and explicit knowledge (Polanyi, 1966, Nonaka et al., 1995, Dalkir, 2010). In his work Polanyi (1966) states that "we can know more than we can tell". According to most definitions, we can summarize that tacit knowledge is the one that individuals attain through experience, it is usually subconscious and sometimes individuals may not be aware of how they manage to accomplish particular results. Tacit knowledge is more difficult to transfer. It is in fact, communicated indirectly, usually through storytelling, metaphor and analogy. Therefore, we believe it is very important for an organization and individuals to capture and codify such knowledge, in order to be aware of it and be able to share it with others.

On the other hand, explicit knowledge is the one that can be more easily attained and is often expressed or documented in a formal, systematic manner frequently in words and numbers, and individuals may easily communicate it to others. Examples include management directives, executive orders, policy manuals, meeting minutes, technical documentation and reference guides.

Another distinction in knowledge types would be creation of "new knowledge" (in example, innovation) and transfer of "established knowledge" within a group or organization. Or if we consider the object of the knowledge it can then vary between management or operational expertise, technical know-how, R\&D results and statistics, company procedures, lessons learnt from work books or other documents, etc.

Very often one individual or organization unit repeats work that has been already executed by other individuals or in other parts of the organization. This may cause not only a waste of time and other resources, but may enhance serious negative consequences for example, work being repeatedly done in a wrong way in a specific situation. In order to avoid this from happening, organizations define and implement different methods and practices of KM.

In a first edition of the research (Terzieva, 2014) we started a study on how organizations actually learn from experience, which methodologies are more commonly preferred. Based on these first results we then explain findings with some further analysis, in particular linking to project management and the team role in the knowledge management process.

\section{Project Management as a trigger for learning from experience}

A project is a temporary effort to create a unique product or service, and has clearly defined starting and ending dates, a specific scope of work to be performed, a budget, and a specified level of performance to be achieved (Lewis et al., 2000). From the definition of a project we can perceive some of its important characteristics: it is limited in time, so it is temporary, and it is unique. It does not mean that projects cannot be similar, but it means that no project is exactly the same as any other, because every project has a unique product or service that is created with available resources. According to this definition, every project represents an opportunity to acquire new knowledge for individuals, and for the organization.

On the other hand, project management methodologies usually define standard project phases, processes, templates or actions that are repeated in the course of different projects. Documenting decisions and assumptions regarding resources, 
time, quality requirements, costs etc., is a way to store and share important information: Why the project idea exists, or what problem is it answering? What are the products or the deliverables of the project going to be? Who will take part in the project, and how will people working on the project be organized? When will the project take place and which are the deadlines? And in the long run, experience enhances the definition of project management best practices.

The importance and the necessity of an efficient utilisation of knowledge in organizations increases (Grillitsch, 2007, Gasik, 2011), and knowledge management is in fact a critical factor for successful process integration (Fugate et al., 2009). Knowledge management enables project team members to reduce rework and time for planning and execution (Ajmal, 2009). Sharing lessons learned and advanced practices, is in fact suggested as a key to helping others excel in project management (Ireland, 2007).

However, experience shows often that managers not always are aware of the learning processes and organizations face challenges on their way to project effectiveness. Part of the difficulties could be blamed on the nature of tacit knowledge, or other may be found in the quantity of knowledge management methods and practices that organizations adopt. In the later paragraphs, we will present photography of how organizations actually turn into action project knowledge management and who are the main players involved.

\section{Project Reviews}

There are four approaches to managerial learning from experience that authors distinguish: intuitive approach, incidental approach, retrospective approach and prospective approach (Mumford et al., 1995). The intuitive approach is when learning from experience is not a conscious process and people who use this approach believe that learning is something natural, something that normally happens through experience but difficult to define what exactly they have learned. In this case knowledge gained by experience is tacit and creates limits to all the advantages that could be attained by sharing it with others.

The incidental approach is characteristic for explaining learning that happens by chance in situations out of the normality.

On the other hand the retrospective approach is when individuals learn from experience though remembering and analyzing what happened and discussing the consequences from situations that occurred. Very often this approach is provoked by mistakes, just as it is with the incidental approach, but people who use the retrospective approach are ready to learn from both positive and negative experiences and make conclusions that later can serve as lessons for them or for others. According to this approach, it is very useful writing down what has been learned in order to preserve it.

The fourth approach is the prospective one. If with all the three previous approaches learning is seen through looking back in the past, the prospective approach concentrates on looking forward and planning to learn in future. The learning process starts with planning to learn, trying to implement the plan, reviewing it later and then making conclusions on the lessons learned. A typical situation where this approach can be turned into learning is in a class, but we should remember that very often lessons learned in a course are not that easily turned into practice.

An interesting phenomenon is that some businesses justify themselves for not introducing retrospectives with the lack of time, others do use retrospectives but without a formal process, some are not aware that "the thing they do at the end of a project" is a project retrospective, and only few perform it as a conscious activity 
of learning from experience and creating knowledge assets for the future. On the other hand, in different organizations there are different synonyms of a retrospective that sometimes only partially mean the exact same concept. For example, it is popular amongst firms to use the term "post-partum" or "post-mortem". The first one is associated with the difficult period that a mother or a child passes after birth, and is not considered very appropriate when approaching learning from experience process. "Post mortem" instead is related to reviewing a project that has not been completed successfully and we will address this particular type of project review later on. In the U.S. Army they talk about Post Engagement Redress or After Action Review, in the U.S. Navy: Navy Lessons Learned (Kerth, 2001).

Taking a deeper look into what happened is always wiser than hoping to succeed somehow next time that a particular situation occurs. The benefits from a project review can be analyzed on three different levels: management, teams and individuals.

Management benefits are defined mainly by understanding better the way that the organization works and by learning to distinguish between common causes and extraordinary causes of variations in the processes that form the project. By involving everyone associated with the project and reviewing the stories of all participants the management gains a complete view of the "big picture" of all processes, decisions and dynamics. This ensures an opportunity to conduct a fact based management, develop a future plan for improvement and predict the consequences of eventual changes that may be introduced.

Project managers, in particular, learn how to improve project management methods and to find new ways to ensure that project goals are met. A retrospective enhances a full view of the situation and challenges managers to confront their point of view with others, hear what they have to say and record new information that individuals have gained through their work on the project. The difference in perceptions between individuals is what enables knowledge related process of creating new knowledge through recombining already existing knowledge elements.

On a team-level, teams learn new alternatives to designing roles and responsibilities in order to enhance efficiency, but not only. Taking action to improve future work and performance creates a sense of control over the team's activities and increases job satisfaction, improves work environment, and motivation to collaborate. The more team members discuss and analyse their actions in a constructive way the better they share their lessons from personal experience get to know each other and understand how every member thinks and what personal knowledge assets he has gained.

For individual contributors learning through a project review helps them understand how to improve tasks and deliverables to increase their personal effectiveness. They understand which actions accomplished by others or themselves have demonstrated positive effects on performance and which could be considered as mistakes.

However, passing from theory to practice is not easy and requires efforts and choices that companies take on according to their maturity, culture and context. In this research, we will try to explore and understand what choices the participants in our survey have made in order to manage knowledge.

\section{Methodology}

Our study is focused on investigating on which phase of the knowledge management life cycle are organizations paying more attention to, and at which 
level is knowledge sharing and reusing more active: individual, team or organizational - level.

Our research has three main phases as shown in figure 1. It starts with considerations from project management experience, two initial interviews described below, and existing literature. Next, inspired by Dalkir's (2010) list of possible methods and practices of tacit and explicit knowledge transfer and preservation (APQC, 2003, Dalkir, 2007, Liebowitz, 2008), we define a list of possible methods and practices that are related to project management (Table 1.). A short survey with closed-ended questions is then run in order to explore which methods and practices (refer to Table 1), are actually adopted in different real life working realities. Investigated cases are from both Italian and International companies, represented by twelve project/porffolio management professionals from different sectors: automotive, banking, insurance, consumer goods, service management.

Figure 1

Approach
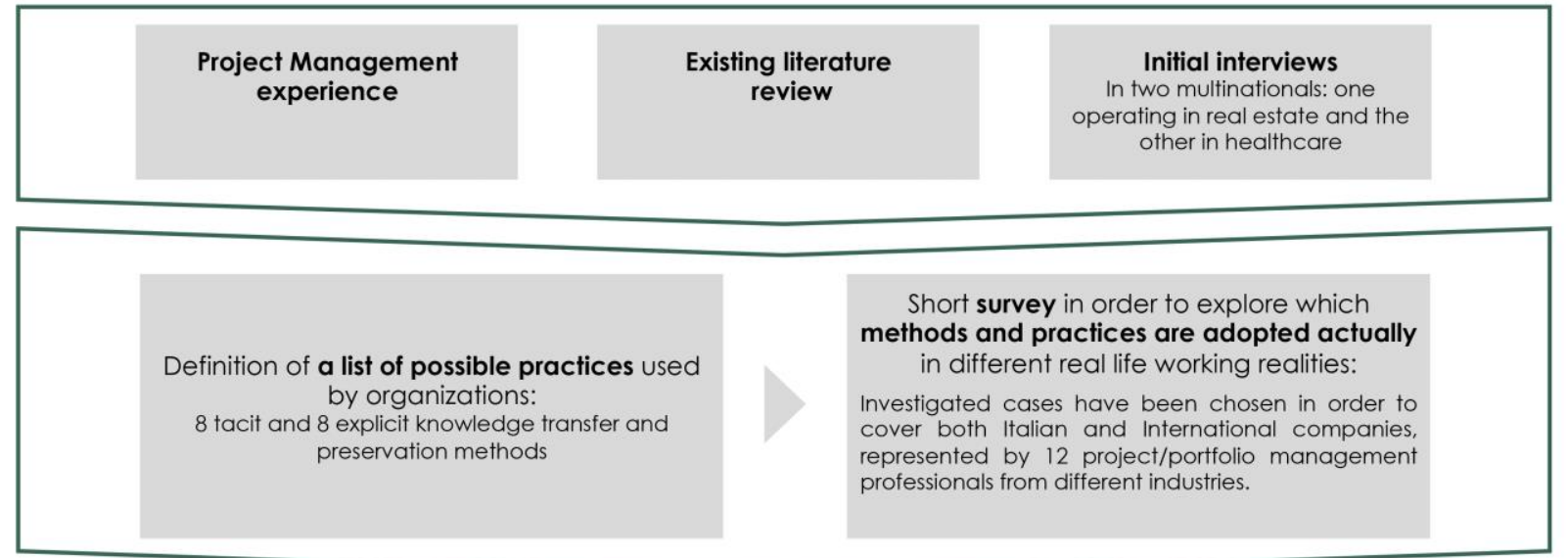

Follow-up interviews, final analysis and conclusions

Source: Author's illustration

Table 1

Possible Knowledge Transfer and Preservation Methods

\begin{tabular}{ll}
\hline Explicit Knowledge & Tacit Knowledge \\
\hline $\begin{array}{l}\text { Demand / Project Management Software } \\
\text { tools }\end{array}$ & $\begin{array}{l}\text { Networks (internal social networks or } \\
\text { communities, knowledge sharing forums) }\end{array}$ \\
\hline Shared project folders, shared drives & Interactive Project Management training \\
\hline Intranets, portals, shared networks & Coaching and mentoring programs \\
\hline Shared Project Management manual & Videotaping \\
\hline Formal training program content & Storytelling \\
\hline $\begin{array}{l}\text { Project Management documentation } \\
\text { templates }\end{array}$ & $\begin{array}{l}\text { After action reviews, project status reviews, } \\
\text { project post-mortem sessions etc. }\end{array}$ \\
\hline FAQs & Exit Interviews \\
\hline Shared status reports, program/portfolio & $\begin{array}{l}\text { Emeritus or alumni programs (whereby } \\
\text { retirees are still kept "connected" to the } \\
\text { master plans, etc. }\end{array}$ \\
\hline
\end{tabular}

Source: Terzieva (2014) 
After the survey, we conducted follow-up interviews with participants in order to obtain more details for analysis and discussion. The survey aimed to gather numerical information of which practices where used, then interviews focused on the practices that have been confirmed during the survey. For example, if shared folders where used, we investigated further who they were shared with in the company. In the next sections we illustrate the findings that we consider most interesting and suggest conclusions.

\section{Results}

\section{Case studies - initial interviews}

In order to understand how organizations approach learning from experience through project management, we will now see two case studies conducted in two international companies, which for privacy reasons, will be called Company A and Company B (Table 2). During interviews it has been discussed with department/project managers how each one approaches project reviews and knowledge sharing.

A brief presentation of the arguments has been sent to all participants in the survey before the interviews. As the terminology used for specific activities in every company is different, it was important not to influence the participants with definitions that have been used in this study and the presentation contained a series of questions that they would have been asked:

- What kind of projects do you work on?

- What are the dimensions of the team and is the team always the same or it is formed for every project?

- What is the normal duration of a project?

- Can you give me examples of problems or difficulties that you had to face during your last project?

- Do you review projects? How?

- Do you write reports? If yes, who does exactly and whom are they addressed?

- Do you organize meetings in order to discuss how a project went?

- If yes, who participates at these meetings, how long do they last, where are they organized?

- What happens with new information? How is it saved and shared?

- Do you have any formalized methodology of learning from experience?

- Could you give me some examples of the arguments that are treated in reports or reviews?

- And examples from your personal experience for how you learned new lessons on a project that resulted useful while working on another project?

Company $A$ is a Real Estate company that manages real estate funds and we talked with the responsible of acquisitions. Projects usually run in two major phases: one first part that consists in process underwriting that lasts about two to three months if not under pressure, and a second part from three to four years after a deal is closed that regards asset management.

The team that works on the projects is rather stable in time and usually includes a managing director who is responsible of strategic decisions, an analyst that does the numerical evaluations, and an associated project responsible that coordinates different contracts. The stability of the team determines well established relations and coordination between team members. This in its behalf enhances a positive environment in which projects are developed. According to the theory that we have 
examined so far, we can predict that in such teams it is less probable that it would be necessary to concentrate on interpersonal difficulties when reviewing projects. And this is exactly what the company's interlocutor confirms. On the meeting that are organized in order to discuss past project, it is rare that topics like teambuilding or those regarding emotions are treated. Interpersonal issues, apart of some specific situations, are usually left to individual initiatives or occasional practices.

At Company A we can distinguish three types of meetings that are organized in order to review work and discuss important issues. The first type of meeting is conducted more or less every three months, in London at an international level, and is leaded by senior management from London. The main topics on which the participants reflect then are the investment opportunities on which al regional teams have been working on. This kind of meetings enables learning processes not only from personal experience but also from the experience of other teams that work on similar projects. Talking with colleagues from other countries about one's successes of failures enhances capturing new knowledge and learning a rich variety of lessons.

A second practice used in the company is at a regional level. Every week the members of the team, including junior members, discuss on-site with the managing directors the ongoing problems and important issues. These meetings are considered very useful for improving performance and accessing knowledge assets that everyone has gained individually. At the end of every weekly meeting, a minute report is saved, and in this way all events, that might seem even irrelevant at the time that they occur, can be registered in the "organizational memory" and consulted at the end of the project if needed.

The third type of meetings for reviewing projects and experience is organized offsite and last a couple of days. For example, all European teams meet in Hamburg where they participate in different discussions and exercises. These gatherings are dedicated to elaborate on more in detail topics that are both common to all projects and characteristic for particular projects or events only. This type of meeting that the company organizes is the one that can be compared most easily to what Kerth (2001) calls a project retrospective. It is always off-site and lasts a couple of days which ensures better concentration on the project review and gives participants a chance to focus on reflecting how to improve performance. The bigger variety of presentations and exercises that are proposed to the individuals enables a rich knowledge flow. Usually senior managers are invited to present specific cases that are given as examples for best practices and other cases that have faced serious problems. In this way, individuals review projects, share knowledge and analyse possible actions to implement in order to resolve problems and learn from the successes and mistakes that have been accomplished during the past

A common impression among individuals that take part in all three types of meetings is that they are very helpful and important because they give an opportunity to stop for a while and reflect on issues that are relevant but for which they would not find time to think while busy with ongoing responsibilities. The enthusiasm in participating is influenced also by the fact that meeting colleagues from other countries gives the opportunity to compare personal experience with a wide range of different people and to widen one's social network.

In the case of Company B, a multinational operating in Healthcare, instead in the interview took part the marketing responsible for Italy and the assistant responsible of marketing for Europe. In this second case study that we are examining teams are usually composed of a bigger number of people as they are organized mainly by region. A medium size team consists of about fifty or sixty individuals that are not 
always present on all projects. A normal duration of the projects are from three to four months but results can be observed after about two years.

These project characteristics define the first observation that can be made. Performance and problems regarding projects are reviewed according to two different organizational practices. One is evaluating initiatives every two years in order to control what are the results in the long run. As we concluded, according to the theory review, the best time for running a project retrospective oriented to reflect on actions and events that occurred would be at the end of the project but not too far after it. Two years is quite a long time for individuals to remember what exactly happened, why they decided to act in a certain way and what where the concrete consequences of their actions. These considerations agree with the fact that there is an established practice in the company to give continuous feedback on projects and on all products that they include. Managers personally perform calls to verify if results are being accomplished. Reports from project reviews organized every trimester are conserved as sources of information to be consulted in future and the company uses a well-developed information system that supports sharing of information. There is a complete data base of sales registered during the years that can be accessed in every moment.

The second kind of meetings are scheduled at every quarter and are organized always off-site where the teams spend one week on reviewing the projects that they have been working on. In Company $B$ these initiatives are run both in every country and on an international level where teams from all regions meet together. The project reviews involve usually managers, in charge of marketing and sales departments. Back-office and middle-office employees are not invited to participate directly but contacted virtually for feedback on the activities that they work on.

Table 2

Interview Results

\begin{tabular}{|c|c|c|}
\hline Company & A & B \\
\hline Business sector & Real Estate & Healthcare \\
\hline $\begin{array}{l}\text { Average project } \\
\text { duration }\end{array}$ & Six months & Four months \\
\hline $\begin{array}{l}\text { Team general } \\
\text { description and } \\
\text { key members }\end{array}$ & $\begin{array}{l}\text { Rather stable in time, includes: } \\
\text { managing director, analyst, and } \\
\text { associated project responsible, } \\
\text { that coordinates activities. }\end{array}$ & $\begin{array}{l}\text { Fifty or sixty individuals that might } \\
\text { vary for every project, typically a } \\
\text { project manager coordinates the } \\
\text { team. }\end{array}$ \\
\hline $\begin{array}{l}\text { Project team } \\
\text { meeting types }\end{array}$ & $\begin{array}{l}\text { 1. Every three months at } \\
\text { international level. } \\
\text { 2. Every week at regional level. } \\
\text { 3. Occasional meetings } \\
\text { organized off-site, that last a } \\
\text { couple of days. }\end{array}$ & $\begin{array}{l}\text { 1. Every two years results review. } \\
\text { 2. Quarterly, project status review. }\end{array}$ \\
\hline $\begin{array}{l}\text { Documentation } \\
\text { sharing }\end{array}$ & $\begin{array}{l}\text { Meeting minutes, project plans \& } \\
\text { documentation exchanged by } \\
\text { email }\end{array}$ & $\begin{array}{l}\text { Shared data base of sales initiatives } \\
\text { registered during the years that can } \\
\text { be accessed in every moment }\end{array}$ \\
\hline
\end{tabular}

Source: Authors

One of the exercises that are scheduled as first in the project retrospective meeting are those regarding team building. Such exercises are drawn to make the individuals stop and take a breath from stress or eventual conflicts that could have occurred during the project. Then prepare the participants for the review and let 
them refresh their energy for the future project that they will work on. As we already saw, teams that work on different projects are rather not stable in time and developing a team spirit is very important to enhance their effective collaboration. On the other hand even if the team remains the same, given its dimensions, it is possible that not all members have had the possibility to establish a good relationship that ensures best coordination and communication. These activities let people release the tension that they have accumulated during the last days of the project by making them play. An interesting finding from this second interview is that management invests in the initiatives, but not all participants see the benefits of the time spent off-site. This might be explained by dynamic work rhythm or by insufficient management sponsorship.

\section{Survey on knowledge transfer and preservation methods}

Based on this first investigation on how companies manage project knowledge, eight tacit and eight explicit knowledge transfer, preservation methods have been identified, and twelve project management professionals have been chosen in order to explore their experience, and obtain results that investigate same practices in different industries. We asked questions aiming to detect which of the suggested practices from Table 1 are used in the organizational reality they represent.

Table 3

Results on Explicit Knowledge Transfer and Preservation Methods

\begin{tabular}{lll}
\hline Methods & $\begin{array}{l}\text { Number of } \\
\text { organizations that } \\
\text { confirmed practice }\end{array}$ & Percentage \\
\hline Shared project folders, shared drives & 12 & $100 \%$ \\
\hline Intranets, portals, shared networks & 12 & $100 \%$ \\
\hline $\begin{array}{l}\text { Shared status reports, program/portfolio master } \\
\text { plans, etc. }\end{array}$ & 12 & $100 \%$ \\
\hline Project Management documentation templates & 11 & $92 \%$ \\
\hline Demand / Project Management Software tools & 10 & $83 \%$ \\
\hline Formal training program content & 7 & $58 \%$ \\
\hline Shared Project Management manual & 5 & $42 \%$ \\
\hline FAQs & 3 & $25 \%$ \\
\hline SOurce: Terz
\end{tabular}

Source: Terzieva (2014)

Table 4

Results on Tacit Knowledge Transfer and Preservation Methods

\begin{tabular}{lll}
\hline Methods & $\begin{array}{l}\text { Number of } \\
\text { organizations that } \\
\text { confirmed practice }\end{array}$ & Percentage \\
\hline $\begin{array}{l}\text { After action reviews, project status reviews, project } \\
\text { post-mortem sessions etc. }\end{array}$ & 12 & $100 \%$ \\
\hline $\begin{array}{l}\text { Networks (internal social networks or communities, } \\
\text { knowledge sharing forums) }\end{array}$ & 6 & $50 \%$ \\
\hline Coaching and mentoring programs & 5 & $42 \%$ \\
\hline Interactive Project Management training & 3 & $25 \%$ \\
\hline Storytelling & 3 & $25 \%$ \\
\hline $\begin{array}{l}\text { Emeritus or alumni programs (whereby retirees are still } \\
\text { kept "connected" to the organization) }\end{array}$ & 3 & $25 \%$ \\
\hline Videotaping & 1 & $8 \%$ \\
\hline Exit Interviews & 1 & $8 \%$ \\
\hline Source: &
\end{tabular}

Source: Terzieva (2014) 
Some of our research results presented in Tables 3 and 4, show that explicit knowledge management methods are more commonly applied and some of them are confirmed by all participants in the survey.

Videotaping, Storytelling, Exit interviews and Emeritus or alumni programs result to have low frequency instead, we suppose, because of the nature of tacit knowledge and the effort required to capture it, but also due to low visibility these practices have in organizations.

In order to understand better these numbers further details have been taken into consideration. In particular, we took a deeper look on three of the practice groups that are most confirmed.

First interesting findings for example, are related to shared project folders: in all cases folders are shared with project team members, but in five of those documentation is not consigned neither to a Project Portfolio Office for monitoring and analysis nor is it shared with other project teams (Table 5).

Table 5

Focus on Users of Shared Project Folders and Shared Drives

\begin{tabular}{llll}
\hline Practice & $\begin{array}{l}\text { Shared with Project } \\
\text { Team }\end{array}$ & $\begin{array}{l}\text { Shared with } \\
\text { Project/Portfolio } \\
\text { Office (for project } \\
\text { status analysis) }\end{array}$ & $\begin{array}{l}\text { Shared at } \\
\text { organizational level } \\
\text { with other project } \\
\text { teams }\end{array}$ \\
\hline $\begin{array}{l}\text { Percentage of } \\
\text { participants that } \\
\text { confirmed practice }\end{array}$ & $100 \%$ & $58 \%$ & $25 \%$ \\
\hline Source:Austhe & & \\
\hline
\end{tabular}

Source: Authors

We then explored the recipients of shared status reports and program/portfolio master plans. In Table 6 we can observe that Status Reports and Master Plans are addressed always to top management, and almost always, in $75 \%$ of cases, shared with the project teams.

Table 6

Focus on Shared Status Reports and Program/Portfolio Master Plans

\begin{tabular}{lll}
\hline Practice & $\begin{array}{l}\text { Addressed to Top } \\
\text { Management }\end{array}$ & $\begin{array}{l}\text { Addressed to Top } \\
\text { Management and All Project } \\
\text { Teams }\end{array}$ \\
\hline $\begin{array}{l}\text { Percentage of participants } \\
\text { that confirmed practice }\end{array}$ & $100 \%$ & $75 \%$ \\
\hline
\end{tabular}

Source: Authors

After action reviews, project status reviews, project post-mortems etc. instead, can be analysed according to the specific type: in all cases, project status meetings are regularly conducted, and in only one, there are organized project reviews/postmortems after highly strategic initiatives (Table 7). "Project Status Meetings During Project Execution", scheduled approximately two to four times a month, are confirmed by all participants. While "Project Review / Project Post-mortem at the end of the Project", for only highly strategic project, is less frequently observed. 
Business Systems Research | Vol. 7 No. 1 | 2016

Table 7

Focus on After Action Reviews, Project Status Reviews, Project Post-Mortems

\begin{tabular}{|c|c|c|c|c|}
\hline Practice & $\begin{array}{l}\text { Project Status } \\
\text { Meetings During } \\
\text { Project } \\
\text { Execution } \\
\text { (approximately } \\
2 \text { to } 4 \text { times a } \\
\text { month) }\end{array}$ & $\begin{array}{l}\text { Project Review / } \\
\text { Project Post- } \\
\text { mortem at the } \\
\text { end of the } \\
\text { Project (only } \\
\text { highly strategic } \\
\text { projects) }\end{array}$ & $\begin{array}{l}\text { Area or } \\
\text { Department } \\
\text { Review } \\
\text { Meetings } \\
\text { (approximately } \\
2 \text { to } 4 \text { times a } \\
\text { month) }\end{array}$ & $\begin{array}{l}\text { High Level } \\
\text { Company } \\
\text { Action Review } \\
\text { Meetings } \\
\text { (approximately } \\
1 \text { to } 6 \text { times a } \\
\text { year) }\end{array}$ \\
\hline $\begin{array}{l}\text { Percentage of } \\
\text { participants that } \\
\text { confirmed } \\
\text { practice }\end{array}$ & $100 \%$ & $8 \%$ & $50 \%$ & $17 \%$ \\
\hline
\end{tabular}

Source: Authors

\section{Discussion}

Part of the results confirmed what literature preview predicted but a more detailed look suggests that organizations are being creative looking for different combinations of practices and methods for knowledge management. The survey findings lead us to the conclusion that there are two important trends among analysed companies. First, we can read results (Table 3, Table 4) as a sign that a lot of effort is being made by organizations to capture, store and share knowledge, but more actions could be done to ensure the re-use of it. Second, cross team knowledge sharing is sometimes limited (Table 5, Table 6). We assume that learning form experience then is more active at single team level or it is conveyed through information flows from team experiences versus top management, and less likely versus other teams.

A further literature research helps us compare and explain out findings. In their study, Inkpen et al. (1998) describe how successful experience transfer is facilitated by similarity in source and recipient context. Markus (2001) also analyses knowledge sharing phases and suggests how knowledge sharing processes depend on reuse situations according to the type of knowledge reuser and also depend on knowledge repositories that are created. We can see how according to this study, when the creator and the receiver of the knowledge is the same team that work together, for example, then sharing and reusing knowledge results most easy and likely to happen. When sharing of knowledge is between members of the same community, it is also confirmed that they easily reuse it, but might have difficulties in finding and selecting the knowledge they need. The third case where defining knowledge needs and finding knowledge to reuse seems more difficult at all stages, is when it happens at expertise-sharing level. Creating repositories is confirmed to have a very important role in successful knowledge reuse, on the condition that companies pay attention to costs, to incentives for knowledge producers, and to the definition of intermediaries, human and technical, in order to manage and facilitate the process.

The importance of teams and team working for learning from experience is acknowledged in approaches like Team-Based Learning (Michaelsen et al., 2009) proposed for college small-group learning, and Agile and Lean frameworks.

We saw how according to the survey explained in the previous paragraph of the paper, retrospectives at the end of the project seem to be less adopted than practises aiming to review partial results and to assess progress during the project implementation. Repositories are also less likely to be shared at a cross team level, 
according to our findings. Status reports addressed to both top management and teams can be explained as a necessity to control work progress, rather than as an effort limited to knowledge sharing. The key role of the team can then be motivated with the match between source and receiver, the same project team, and in the perceived benefits, that will occurred during the same project.

Agile and Lean frameworks (Larman et al., 2008, Gonçalves et al., 2014) that support the sharing of experience, and enhance learning from each other, suggest short cycle reviews that include the definition of concrete action plans aiming to improve the way the team works and its performances. It is interesting to notice how according to this approach, reviews, actions and benefits of taken actions start and finish exactly inside the team. We can easily agree that, if this practice is correctly implemented, it is expected to bring results faster, and motivates the team to continue exchanging knowledge and taking actions. In their book Gonçalves et al. (2014) explore the art of agile retrospectives and explain how to get value out of them.

We believe that companies should use the potential of teams for generating and sharing knowledge, as they already do in the majority of cases that we examined. Much more can be done to enhance knowledge reuse and obtain all possible benefits from it. Team members contribute to the project and to the organization more than just with their knowledge and skills. Social relationships and networks enhance project success (Leonard et al., 2014) and according to our findings create opportunities for effective knowledge sharing.

Some authors, in fact, see not only technical factors for knowledge sharing, as information systems and repositories, but evidence the importance of the psychosocial factors too (Zàrraga et al., 2003). A positive team environment not only will enhance knowledge sharing but also will ensure competitive advantage for the company. The team strengthens its competencies and these are shared between members. In this way if single resources leave, knowledge can be preserved within the company.

\section{Conclusion}

Efficient knowledge management maximizes internal efficiency, profitability and ensures competitive advantage to the organization, but it should not be considered as a ready "receipt" for better quality and performance, that can be directly applied to any organization and in any moment. It is crucial to adopt a knowledge management strategy that will be suitable for the organization. Project management offers inputs for an efficient knowledge management as, for its nature, combines processes that repeat in time and enhance specialization and knowledge consolidation, and on the other hand refers to unique initiatives that introduce new knowledge and experiences.

Project teams in particular result to be a key factor for activating knowledge reuse. Further research however should focus on success factors at company level. An interesting question this work does not answer is how organizations should enhance knowledge reuse between different teams. The phenomenon could be analysed by gathering further information and expanding sample size. The study described in this work should be considered as a more general investigation on knowledge management practices through project management. Involving a larger number of professionals, in future research, might also procure data for possible comparison of wider practices, industries and countries. 


\section{References}

1. Ajmal, M. M. (2009), "Managing Knowledge in Project-based Organizations: A Cultural Perspective", Vaasa University Press, Vaasa, pp.169.

2. APQC (American Productivity and Quality Centre) (2003), "Capturing critical knowledge from a shifting workforce", Houston, Texas.

3. Buckley, S., Jakovljevic, M. (2013), "Knowledge Management Innovations for Interdisciplinary Education: Organizational Applications.", IGI Global, Hershey, PA, pp.1-486.

4. Collison, C., Parcell, G. (2004), "Learning to Fly; Practical Knowledge Management from Leading and Learning Organisations", Capstone Publishing Ltd., 2nd edition.

5. Dalkir, K. (2007), "Characterization of knowledge sharing channels on the Internet", Bolisani E., Building the Knowledge Society on the Internet: Making Value from Information Exchange, Idea Publishing Group, pp. 89-119.

6. Dalkir, K. (2010), "La continuité du savoir : préservation et transmission du savoir dans le secteur public", Télescope, Vol. 16, No.1, pp.146-167.

7. Fiol, C. M., Lyles, M. A. (1985), "Organizational Learning", The Academy of Management Review, 10(4), pp.803-813.

8. Fugate, B. S., Stank, T. P., Mentzer, J. T. (2009), "Linking improved knowledge management to operational and organizational performance", Journal of Operations Management, 27, pp. 247-264.

9. Gasik, S. (2001), "A Model of Project Knowledge Management", Project Management Journal, Vol. 42, Iss. 3, pp. 23-44.

10. Gonçalves, L., Linders, B. (2014), "Getting Value out of Agile Retrospectives - A Toolbox of Retrospective Exercises", Lulu.com, United States.

11. Grillitsch, W., Müller-Stingl, A., Neumann, R. (2007), "Successful Sharing of Project Knowledge: Initiation, Implementation and Institutionalisation", The Electronic Journal of Knowledge Management, Vol. 5, Iss. 1, pp.19-28.

12. Inkpen, A., Dinur, A. (1998), "The Transfer and Management of Knowledge in the Multinational Corporation: Considering Context", Working Paper, Carnegie Bosch Institute, pp.98-16.

13. Ireland, D. (2007), "Sharing Experiences In Project Management", Prez sez 2.

14. Kerth, N. L. (2001), "Project retrospectives: a handbook for team reviews", Dorset House Publishing, New York.

15. Larman, C., Vodde, B. (2008), "Scaling Lean \& Agile Development: Thinking and Organizational Tools for Large-Scale Scrum", Addison-Wesley Longman.

16. Leonard, A., Zyl, D. (2014), "Social relationships in IT project teams: its role, complexity and the management thereof", International Journal of Information Systems and Project Management, Vol. 2, No. 1, pp. 21-39.

17. Lewis, J.P. (2000), "The Project Manager's Desk Reference", 2nd ed., New York, McGraw-Hill.

18. Liebowitz, J. (2008), "Knowledge retention strategies and solutions", Boca Raton, CRC Press Floride.

19. Markus, M. L. (2001), "Toward a Theory of Knowledge Reuse: Types of Knowledge Reuse Situations and Factors in Reuse Success", Journal of Management Information Systems, 18, 1 (Summer), pp. 57-93.

20. Michaelsen, L. K., Sweet, M., Parmelee D. X. (2009), "Team-Based Learning: Small Group Learning's Next Big Step: New Directions for Teaching and Learning", Jossey-Bass.

21. Mumford, A. (1995), "Putting learning styles to work: an integrated approach". Industrial and Commercial Training, Vol. 27, Iss. 8, pp. $28-35$. 
22. Newman, B., Conrad, K.W. (1999), "A Framework for Characterizing Knowledge Management Methods, Practices, and Technologies", First Publication, in support of The Introduction to Knowledge Management, George Washington University Course EMGT 298.T1.

23. Nonaka, I., Takeuchi, H. (1995), "The Knowledge-Creating Company. How Japanese Companies Create the Dynamics of Innovation", Oxford University Press, New York.

24. Pfeffer, J., Sutton, R. (1999), "The knowing-doing gap: How smart companies turn knowledge into action", Harvard Business School Press, Boston, MA.

25. Polanyi, M. (1966), "The Tacit Dimension", Routledge, London.

26. Senge, P. (1994), "The fifth discipline: the art and practice of the learning organization", Currency Doubleday, New York.

27. Senge, P., Kleiner, A., Roberts, C., Ross, R., Roth, G., Smith, B. (1999), "The Dance of Change. The challenges of Sustaining Momentum in Learning Organizations", A Fifth Discipline Resource, London.

28. Terzieva, M. (2014), "Project Knowledge Management: how organizations learn from experience", paper presented at CENTERIS 2014 - Conference on ENTERprise Information Systems / ProjMAN 2014 - International Conference on Project MANagement / HCIST 2014 - International Conference on Health and Social Care Information Systems and Technologies, Troia.

29. Walsh, J.P., Ungson, G.R. (1991), "Organizational Memory", The Academy of Management Review, Vol.16, No. 1, pp. 57-91.

30. Zàrraga, C., Bonache, J. (2003), "Assessing the team environment for knowledge sharing: an empirical analysis", Int. J. of Human Resource Management, 14, 7 November 2003, pp. 1227-1245.

\section{About the authors}

Mariya Terzieva is a research manager and IPMA Level C, certified Project Manager. Mariya has finished Master of Science in Organisation and Information Systems at Bocconi University, Milan, and is practicing business consultant. Research interests and lecturing experience are project and portfolio management, project retrospectives, knowledge management, organisational "fashions", team building, innovation and ICT. Author can be contacted at mariya.terzieva@btoresearch.com

Vincenzo Morabito has graduated in Economics at LUISS and obtained a PhD in Management at Bocconi University. Currently he is Associate Professor at the Management \& Technology Department of Università Commerciale Luigi Bocconi, Milan, Italy, where he is in charge of the course of Information Systems Management and teaches Business Organization and Information Systems for Human Resources. In the past he has been Director of the Master in Information Systems at Bocconi University, after a period as Research Scholar at CISR (Center for Information System Research), MIT Sloan School of Management (2006), and as Research Scholar at the "Decision and Information Science Department" of University of Florida (2005/2006). He has participated in various research projects, many financed by Italian Ministry of University and Scientific Research (Ministero dell'Università e della Ricerca Scientifica e Tecnologica) and has published articles in many journals such as CACM, JIT, European Journal of Information Systems. Author can be contacted at vincenzo.morabito@unibocconi.it 